\title{
Penggunaan Sildenafil pada Anak dengan Hipertensi Pulmonal
}

\author{
Sri Endah Rahayuningsih, Nono Sumarna, Armijn Firman, Dani Kurnia
}

\begin{abstract}
Hipertensi pulmonal merupakan penyakit yang jarang akan tetapi mempunyai tingkat mortalitas yang tinggi. Peran vasodilator, menurut beberapa penelitian dapat meningkatkan survival rate pasien hipertensi pulmonal. Beberapa laporan kasus memperlihatkan efektifitas sildenafil sebagai PDE5 inhibitor dalam menurunkan tekanan rata-rata arteri pulmonal. Oleh karena itu sildenafil dapat dipertimbangkan sebagai pilihan terapi untuk anak dengan hipertensi pulmonal
\end{abstract}

Kata kunci: sildenafil, hipertensi pulmonal

$\mathcal{H}$ ipertensi pulmonal merupakan suatu keadaan terjadinya peningkatan tekanan rata-rata arteri pulmonalis lebih dari 25 $\mathrm{mmHg}$ pada saat istirahat atau lebih dari $30 \mathrm{mmHg}$ pada saat latihan. ${ }^{1,2}$ Pada keadaan normal tekanan arteri pulmonalis (sistolik/diastolik) anak dan dewasa adalah $20 / 12 \mathrm{mmHg}$ dan tekanan rata-rata arteri pulmonalis adalah 15 mmHg. ${ }^{1}$

Hipertensi pulmonal primer pada umumnya bersifat progresif dan berakibat fatal. ${ }^{4}$ Hipertensi pulmonal yang tidak teratasi (tanpa melihat etiologinya) dapat menimbulkan gagal jantung kanan. ${ }^{3}$ Akhir-akhir ini dengan semakin berkembangnya ilmu pengetahuan, teknologi dan tata laksana hipertensi pulmonal, tampak menunjukkan harapan hidup pada hipertensi pulmonal. ${ }^{3,5}$

Selama dekade terakhir ini, vasodilator merupakan pilihan terapi yang utama sebagai obat penghambat vasokontriksi arteri pulmonalis khususnya pada hipertensi pulmonal primer. Berbagai jenis obat-obatan dari kelas yang berbeda telah dipergunakan pada pasien hipertensi pulmonal seperti agonis adrenergik

Alamat Korespondensi :

Sri Endah Rahayuningsih, dr., Sp.A

Bagian/SMF Ilmu Kesehatan Anak FKUP/RSUP dr. Hasan Sadikin Jl.

Pasteur No. 38 Telp./Fax. 2034426-203595 Bandung 40161 (isoproterenol), vasodilator arteri (hidralazin), nitrat (nitrogliserin), angiotensin converting enzyme inhibitor (kaptopril) dan prostaglandin; tetapi sebagian besar dari obat tersebut telah ditinggalkan mengingat efek samping yang ditimbulkannya. Untuk itu para peneliti telah lama mencari vasodilator ideal yang bekerja spesifik pada pembuluh darah paru dan secara nyata menurunkan tekanan arteri pulmonal. ${ }^{6,7}$

Sildenafil yang banyak dikenal sebagai obat disfungsi seksual ternyata mempunyai peran yang cukup besar dalam menurunkan tekanan arteri pulmonal melalui perannya sebagai vasodilator. Dari berbagai penelitian yang telah dilakukan, penggunaan sildenafil sebagai terapi tunggal maupun kombinasi memperlihatkan efek samping yang minimal dan efektifitas yang baik dalam terapi hipertensi pulmonal khususnya pada hipertensi pulmonal primer. Di dalam naskah ini akan dibahas penggunaan Sildenafil pada anak dengan hipertensi pulmonal.

\section{Farmakokinetik Sildenafil}

Sildenafil merupakan phosphodiesterase-5 (PDE5) inhibitor. Dibandingkan organ lainnya, PDE5 ditemukan lebih banyak di paru. Selain aktivitas terhadap PDE5 sildenafil menunjukkan aktivitas terhadap PDE lainnya. Secara invitro, aktivitas sildenafil terhadap PDE5 10 kali lipat dibandingkan 
terhadap PDE6, 4000 kali dibandingkan terhadap PDE3. ${ }^{7-12}$

Nitrit oksida pertama kali merangsang guanylate cyclase. Enzim ini kemudian akan mengubah guanosine triphosphate (GTP) menjadi cyclic 3'-5'- Guanosine monophosphate (cGMP). cGMP kemudian mengaktivasi protein kinase yang akhirnya akan merelaksasi otot polos. Aktivitas cGMP tidak berlangsung terus menerus, tetapi mengalami perubahan menjadi guanosine monophosphate oleh PDE5 sehingga otot polos akan mengalami konstriksi. Sildenafil sebagai phosphodiesterase-5 inhibitor akan menghambat pemecahan cyclic guanosine monophosphate (cGMP). Akumulasi cGMP akan menyebabkan relaksasi kembali otot polos vaskular. ${ }^{7,8,12}$

Struktur kimia sildenafil terdiri dari 1-[[3-(6,7dihydro-1-methyl-7-3-propyl-1 H-pyrazolol[4,3d] pyrimidin-5-yl) -4- ethoxyphenylsulfonyl -4- methylpiperazine cictrate. Sildenafil di absorpsi secara cepat setelah pemberian peroral dengan bioavaibilitas sekitas $40 \%$. Konsentrasi maksimum dalam plasma dicapai dalam waktu 30-120 menit (rata-rata 60 menit). Sildenafil dan metabolik utamanya (N-desmetyl) keduanya mempunyai ikatan dengan protein plasma sebesar 90\%. Protein binding ini tidak tergantung pada konsentrasi total obat. ${ }^{12}$

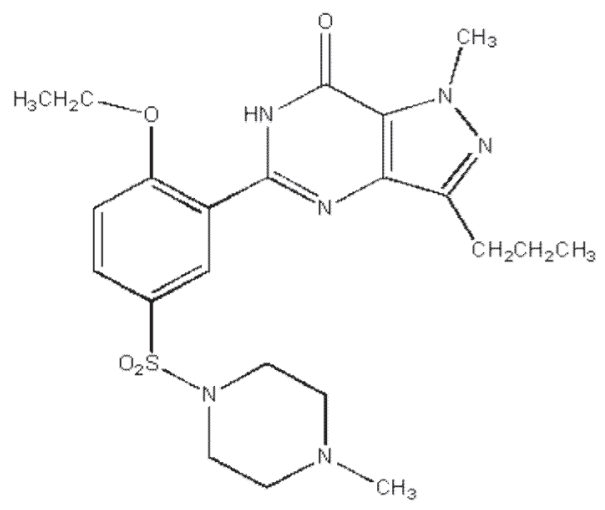

Gambar 2. Struktur kimia Sildenafil Dikutip dari Prasad dkk. $2000^{11}$

Sildenafil mengalami metabolisme melalui dua jalur yaitu jalur mayor dan minor. Jalur mayor melalui P450 2A4 dan jalur minor melalui 2C9 hepatic microsomal isoenzymes. Zat metabolik utama yang bersirkulasi berupa $\mathrm{N}$-desmethyl. Metabolik ini mempunyai kemampuan potensi sekitar 50\% dibandingkan sildenafil. Sesudah pemberian peroral, sildenafil di ekskresikan dalam feses (80\% dari kadar peroral) dan urine ( $13 \%$ dari kadar peroral). Kadar sildenafil meningkat pada pasien dengan gangguan hati, gangguan ginjal dan pemberian bersama obatobatan seperti eritromisin dan simetidin. ${ }^{12}$
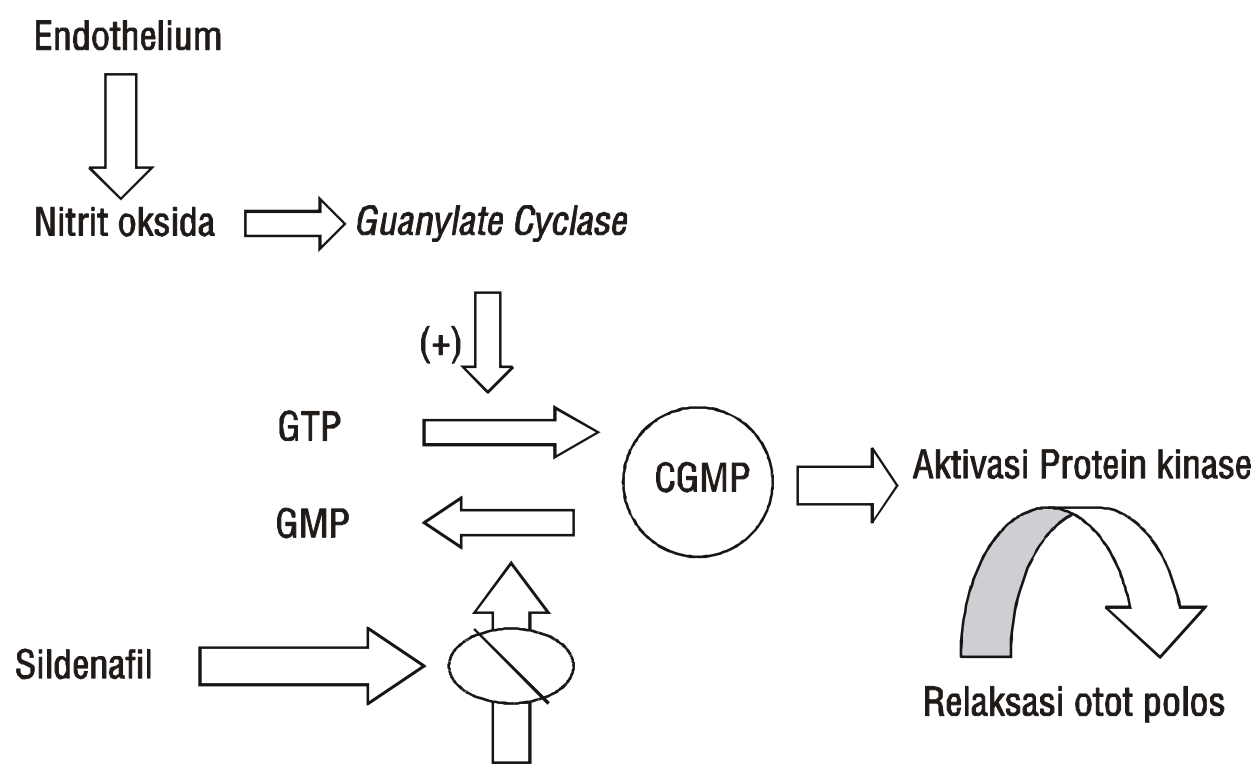

\section{Phosphodiesterase 5}

Gambar 1. Mekanisme kerja Sildenafil Sumber: Abrams D dkk, 2000 
Sari Pediatri, Vol. 6, No. 3, Desember 2004

\section{Penggunaan Sildenafil pada Anak dengan Hipertensi Pulmonal}

Sebelum terapi dengan prostasiklin ditemukan, prognosis hipertensi pulmonal sangat buruk dengan median kelangsungan hidup 10 bulan. Infus prostasiklin tampaknya dapat mengurangi gejala dan mortalitas; tetapi pemberian prostasiklin intravena yang berlangsung terus menerus menimbulkan banyak efek samping sehingga diperlukan terapi oral. Sampai beberapa dekade yang lalu terapi oral yang efektif untuk hipertensi pulmonal adalah dengan pemberian nifedifin yang tidak selektif bekerja pada arteri pulmonalis. Saat ini telah ditemukan sildenafil yang relatif selektif bekerja pada arteri pulmonalis sehingga dapat dipertimbangan sebagai terapi oral pada anak dengan hipertensi pulmonal, walaupun penelitian klinis terhadap penggunaan sildenafil pada anak dengan hipertensi pulmonal masih sedikit dan sebagian besar hanya berupa laporan kasus. ${ }^{7}$

Abrams dkk. melaporkan pemberian sildenafil (dosis $2 \mathrm{mg} / \mathrm{kgBB} / \mathrm{kali}$, 4 kali sehari) pada seorang anak perempuan berusia 4 tahun yang menderita hipertensi pulmonal primer. Pada awalnya pasien ini diobati dengan pemberian nitrit oksida dan prostasiklin. Tetapi tidak menunjukkan hasil yang memuaskan, sehingga kemudian diberikan sildenafil. Pemberian sildenafil ( 4 minggu) menunjukkan saturasi oksigen meningkat dan dapat mencapai 98\% dan tidak mengalami penurunan pada saat menjalani tes jalan kaki selama 6 menit. $^{8}$

Penelitian Mchelakis dkk. menunjukkan peran sildenafil dalam menurunkan tekanan arteri pulmonal rata-rata dan tidak mempunyai efek inotropik negatif. Penelitian ini juga menunjukkan bahwa terapi kombinasi antara sildenafil dan nitrit oksida inhalasi yang bersifat vasodilator pulmonal tidak menyebabkan efek sistemik. Mekanisme ini berkaitan erat dengan efek sinergisme dalam meningkatkan kadar cGMP. Dosis sildenafil yang diberikan pada penelitian ini kurang dari $100 \mathrm{mg}$. Maksimal efek hemodinamik dicapai pada dosis $25 \mathrm{mg}$ dengan durasi sekitar 30 menit. $^{9}$

Kothari dan Duggal, melakukan penelitian terhadap 14 pasien dengan usia antara 5-30 tahun yang menderita hipertensi pulmonal ( 9 hipertensi pulmonal primer dan 5 pasca bedah penyakit jantung bawaan). Pemberian sildenafil dimulai dengan dosis kecil dan dinaikkan secara bertahap. Dosis rata-rata yang digunakan sebesar $87,5 \mathrm{mg} /$ hari pada anak dengan berat badan $<30 \mathrm{~kg}$ dan $150 \mathrm{mg} /$ hari anak dengan berat badan $>30 \mathrm{~kg}$. Parameter yang dinilai berupa kelas fungsional dari New York Heart Association (NYHA), tes berjalan selama 6 menit dan ekokardiografi. Dengan rata-rata pengamatan selama $7,3 \pm 2,4$ bulan (rentang waktu 3-14 bulan), terjadi penurunan kelas fungsional dari NYHA dari $3,31 \pm 0,75$ menjadi $2,0 \pm 0,71 \quad(\mathrm{p}<0,002)$. Terjadi peningkatan jarak tempuh berjalan selama 6 menit dari $264,1 \pm 193,7$ meter menjadi 408,2 $\pm 156,97$ meter selama 3 bulan $(\mathrm{P}<0,001)$ dan $453,2 \pm 159,81$ $(\mathrm{p}<0,0001)$ selama 6 bulan. Tekanan sistolik ventrikel kanan menurun dari $112,40 \pm 45,21$ menjadi $101,86 \pm 47,86 \mathrm{mmHg}(\mathrm{P}<0,002)$. Rata-rata tekanan arteri pulmonal menurun dari $62 \mathrm{mmHg}$ menjadi $47 \mathrm{mmHg}$ pada 4 pasien dengan hipertensi pulmonal primer setelah pemberian selama 7 bulan sildenafil. ${ }^{13}$

Carroll dan Dhillon (2003) melaporkan tiga anak dengan hipertensi pulmonal masing masing akibat penyakit jantung bawaan, pneumonitis interstitial, dan bayi berat badan lahir rendah ternyata menunjukkan penurunanan tekanan arteri pulmonalis yang berbeda beda, walaupun dua diantara pasien tersebut meninggal. Carroll mengemukakan efek sildenafil terhadap penurunan rata rata tekanan arteri pulmonalis tidak tergantung pada penyakit dasarnya. Atas dasar itu Carol dan Dhillon mengemukakakan kemungkinan penggunaan sildenafil pada anak dengan hipertensi pulmonal akibat berbagai keadaan, khususnya hipertensi pulmonal primer, kelainan paru kronik berat dan hipertensi pulmonal persisten pada bayi baru lahir. ${ }^{14}$

Dosis yang direkomendasikan untuk bayi maupun anak anak adalah dosis permulaan yang diberikan 0,5 $\mathrm{mg} / \mathrm{kgBB}$ setiap 6 jam dengan peningkatan dosis 0,5 $\mathrm{mg} / \mathrm{kgBB} /$ dosis sampai tercapai dosis $2 \mathrm{mg} / \mathrm{kgBB}$ tiap 6 jam. Walaupun waktu paruh sildenafil relatif pendek tetapi tidak dianjurkan untuk meningkatkan frekuensi pemberian sildenafil. ${ }^{14}$

Sampai saat ini masih belum banyak penelitian tentang penggunaan sildenafil pada anak dengan hipertensi pulmonal maka maka perlu dilakukan multicentre randomised controlled trial untuk menentukan keamanan dan efektivitasnya. Walaupun demikian dengan mempertimbangkan prognosis yang buruk dan terapi oral lain yang terbukti kurang efektif, tampaknya pada saat ini sildenafil dapat dipertimbangkan sebagai terapi hipertensi pulmonal pada anak. $^{14}$ 


\section{Daftar Pustaka}

1. Park MK. Pulmonary hypertension. Dalam : Pediatric cardiology for practitioners. Edisi ketiga. St Louis : Mosby, 2002. h. 417-26.

2. Barst. RJ. Recent advances in the treatment of pediatric pulmonary artery hypertension. Pediatr Clin North Am 1999; 46:331-41.

3. Nauser TD. Diagnosis and treatment of pulmonary hypertension. American family physician 2001; 63:1789-98.

4. Kinsella JP, Neish SR, Abman S, Wolfe R. Therapy for pulmonary hypertension. Dalam : Garson A, Bricker JT, Fisher DJ, Neish SR, penyunting. The science and practice of pediatric cardiology. Edisi kedua. Baltimore: Williams \& Wilkins, 1998. h. 2345-65.

5. Rich S. Executive summary from the World Symposium on Primary Pulmonary Hypertension 1998, Evian, France, september 6-10, 1998, disponsori oleh the World Health Organization. http://www.who.int/ncd/cvd/ pph.html.

6. Kulik TJ. Pulmonary hypertension. Dalam: Fyler DC, penyunting. Nadas pediatric cardiology. Philadelphia: Hanley \& Belfus, 1992. h. 83-100.

7. Mehta S. Sildenafil for pulmonary arterial hypertension: Exciting, but protection required. Chest 2003; 123:989-92.

8. Abrams D, Neick IS, Magee AG. Sildenafil as a selective pulmonary vasodilator in childhood primary pulmonary hypertension. Heart 2000; 84:1-2
9. Michelakis E, Tymchak W, Lien D, Webster L, Hashimoto $\mathrm{K}$, Archer S. Oral sildenafil is an effective and specific pulmonary vasodilator in patients with pulmonary arterial hypertension. Circulation 2002; 105:2398.

10. Hoeper MM, Galie N, Simonneau G, Rubin LJ. New treatment for pulmonary arterial hypertension. Am J Respir Crit Care Med 2002; 165:1209-13.

11. Prasad S, Wilkinson J, Gatzoulis MA. Sildenafil in primary pulmonary hypertension. N Engl J Med. 2000; 343:1342.

12. Cheitlin MD, et al. Use of Sildenafil (Viagra)in patients with cardiovascular disease. Circulation 1999; 99:167-77.

13. Kothari SS, Duggal B. Chronic oral sildenafil therapy in severe pulmonary artery hypertension. Indian Heart J 2002; 54:404-9.

14. Carroll WD, Dhillon R. Sildenafil as a treatment for pulmonary hypertension. Arch Dis Child 2003; 88:827-8.

15. Grossman W, Braunwald E. Pulmonary hypertension. Dalam : Braunwald E, penyunting. Heart disease. A textbook of cardiovascular medicine. Edisi ke-4. Philadelphia : Saunders, 1992. h. $790-816$.

16. Barst RJ. Medical therapy of pulmonary hypertension. An overview of treatment and goals. Clin Chest Med 2001. http://www.mdconsult.com

17. McLaughlin VV, Rich S. Severe pulmonary hypertensio: critical care clinics. Crit Care Clin 2001. http:// www.mdconsult.com

18. Kulik TJ. Pulmonary hypertension. Dalam: Pediatric cardiac intensive care. Pine JW, penyunting. Baltimore: Williams \& Wilkins, 1998. h. 497-606. 